\title{
Research on the Effect of Private Placement Object on Operating Performance of Listed Companies
}

\author{
Zhaoen $\mathrm{Wu}^{1, \mathrm{a}}$ and Xiaoshun Guo ${ }^{1, \mathrm{~b}}$ \\ ${ }^{1}$ School of Management, Wuhan University of Technology, Wuhan,P.R.China, 430070 \\ a1849872048@qq.com, b739331361@qq.com
}

Keywords: Private placement; Object types of private equity placements; Operating performance

\begin{abstract}
This paper takes 101 listed companies of private placement in China in 2013 as the sample, and uses factor analysis to analyze the performance of private placement companies. Sample Firms will be divided into two categories: to the controlling shareholder or the related party of the private placement of listed companies and new investors to the private placement of listed companies, further analysis of the impact on the performance of the company by the private placement. Empirical results show the private placement of listed companies has a significant role in improving the performance of seasoned equity offerings, and has a positive impact on the performance of the next year; the performance of the private placement to the controlling shareholders or related parties is better than that of the new investors.
\end{abstract}

\section{The Purpose of the Study}

Compared with the public offering of securities private placement, more relaxed in the conditions of issue and audit requirements, lower financing threshold, and thus have the enthusiasm of listed companies on corporate performance, but how to affect the performance of the company? What is the impact of the private placement on the operating performance? For these problems, although a few scholars have studied these, but the conclusions are not the same.

W.D.Zhang[1] by Chinese listed companies issuing new research inject assets during 2006-2007 directional investors found by the cumulative abnormal return and the type of asset injection, when the injection of assets related to company business, long-term investors hold the cumulative excess rate of return higher than the cumulative excess return rate of injection of assets and business does not the correlation. The long-term performance of the listed companies is related to the type of the controlling shareholders, but it is limited to the research on the market performance of the listed companies. P.Zhang and J.Yu[2] in 2009-2010 private placement of listed companies as the research sample, starting from the change of ownership structure of SEO oriented perspective, found that the implementation of the private placement in the operating performance of listed companies increased significantly, after the issuance of business performance continued to decline.

Foreign study found that for new investors (new investors in this paper refers to the private placement of new entrants to become the company's top ten shareholders of institutional investors or individual investors) private placement will affect the market performance of the listed company's performance. Hertzel[3] by institutional investors in the private placement of different shares before and after the discovery, after the issuance of the proportion of institutional investors holding down the company, its long-term performance is significantly worse than the proportion of listed companies rose. However, some listed companies in order to defend the institutional investors interference on the management of the company, and the issuance of shares to investors some negative orientation, these investors will not supervise the negative or participate in the company's management behavior, but only to help the existing management consolidate management right (Barclay et al[4]), which did not reach the purpose of monitoring management. The introduction of institutional investors on corporate performance did not show a positive effect.

However, there are few studies on the performance of the new investors or institutional investors in the domestic research. W.D.Zhang[5] through the research on the private placement announcement effect, short-term market issuance to the controlling shareholder and related parties 
to the directional private placement to non related shareholders and the market performance of non related shareholders in its research does not show that the introduction of a new investor. L.Deng and H.C.Wang[6] of investors' heterogeneous beliefs based on the point in the 2006-2010 years of China's capital market on the private placement of listed companies, investors found that heterogeneous beliefs significantly affect the private placement of shares of long-term market performance, when the offering targets for institutional investors, investors heterogeneous beliefs on the company's share price has more obvious negative to the effect, and further found that the operating performance change and investors' heterogeneous beliefs after the private placement, a significant negative correlation.

In summary, effects of foreign private placement of new investors only influence on market performance is limited, there are few studies domestic issuance of new investors oriented, and individual results to new investors private placement related conclusions and business performance is negative.

In view of this, the purpose of this paper is to explore two aspects: first, whether the private placement can promote the performance of listed companies? Second, the listed companies of different targeted placement, what kind of private placement of the object of the company's operating performance is more significant? For the purpose of the study, we proposed related data for 4 years after issuance of the listed companies on the operating efficiency of the directional empirical analysis; for the purpose of the study two, we proposed different placement objects are divided into two categories: one for the listed company's controlling shareholders or related parties for a class; the new listed company investors (institutional investors or individual investors).

\section{Sample Selection and Research Design}

Sample Selection. The placement of the information and related financial data from the CSMAR database, Shanghai stock exchange and Shenzhen stock exchange. In this paper, the Shanghai and Shenzhen two cities in 2013 to complete the issuance of private placement of listed companies as a whole, there were a total of 217 private placement. According to the purpose of this study is as follows, for the screening of samples: excluding financial listed companies; the lack of the data excluding related listed companies; the elimination of private placement ST corporate sample, in order to prevent the possible influence of earnings management on research purpose; the year two private placement of seven companies because the main purpose is a wholly-owned acquisitions, so as to controlling shareholders or related parties in order to prevent the issuance of the sample; the same listed company in many times during the placement of multiple effects on company performance, excluding the issuance of the year before and after two years occurred in stock, or issuance of Switching Company bonds of listed companies.

Finally, 101 eligible listed companies were identified as samples. We screened the sample, the new investors to the private placement of the company has 66, to the controlling shareholder or other related parties directed additional companies have 35 .

Index Selection. In order to comprehensively evaluate the performance and financial status of listed companies, this paper selects 12 financial indicators from the five aspects of operating capacity, profitability, development, solvency, cash flow capacity to measure the financial performance of Sample Firms[7].

Research Methodology. In this paper, the factor analysis method is used. The method of factor analysis related to the matrix within the original variables from the study of some of the information overlap, the relationship between variables have perplexing boils down to a few public factors a few irrelevant; through the method of dimension reduction[8], the conclusions are not affected by the overall economic environment and capital market volatility and other factors.

The general principle of factor analysis is to extract the common factor, and then calculate the factor score by factor score function. Specific steps are as follows: 


$$
\begin{aligned}
& f_{i}=\sum_{p=1}^{k} b_{i p} x_{p} \\
& F=\sum_{i=1}^{n} c_{i} f_{i}
\end{aligned}
$$

In the two formulas, $f_{i}$ is the common factor score, ${ }^{b}{ }_{i p}$ is the factor value coefficient, $x_{p}$ is the evaluation index system in the index value; $F$ is the enterprise performance comprehensive score, ${ }^{c_{i}}$ is the common factor to explain the variance

\section{The Impact of Private Placement on the Performance of Listed Companies}

In the factor analysis, the annual need of sample variables for KMO test and Bartlett test of sphericity, to measure the correlation between variables in each period is suitable for factor analysis, test results are shown in table 1.

Table 1 KMO and Bartlett test

\begin{tabular}{|l|l|l|l|l|}
\hline year & \multicolumn{1}{|c|}{$\begin{array}{c}\text { Kaiser-Meyer-Olkin metrics for sampling } \\
\text { sufficiency }\end{array}$} & \multicolumn{1}{|c|}{$\begin{array}{c}\text { Sphericity test of } \\
\text { Bartlett }\end{array}$} & df & Sig. \\
\hline 2012 & 0.628 & 900.041 & 66 & 0.000 \\
\hline 2013 & 0.652 & 964.373 & 66 & 0.000 \\
\hline 2014 & 0.508 & 974.710 & 66 & 0.000 \\
\hline 2015 & 0.648 & 1062.889 & 66 & 0.000 \\
\hline 总体 & 0.643 & 7474.286 & 66 & 0.000 \\
\hline
\end{tabular}

From table 1, the KMO value of each period of Sample Firms is greater than 0.5, Bartlett value is relatively large, and the probability of $\mathrm{P}$ value is close to 0 , the value of the test data of the two samples are said to be suitable for factor analysis[9]. After the above steps, we use the model (1) and the model (2) to calculate the score and score of different factors of 2012-2015 years, the results are shown in table 2. It should be noted that the rotation component matrix, the factor value and the total variance table of each period are not shown for space reasons.

Table 2 Factor scores and comprehensive score

\begin{tabular}{|l|l|l|l|l|l|l|}
\hline \multirow{2}{*}{$\begin{array}{l}\text { year } \\
\text { variable }\end{array}$} & \multicolumn{1}{|c|}{$f_{1}$} & \multicolumn{1}{c|}{$f_{2}$} & \multicolumn{1}{c|}{$f_{3}$} & $f_{4}$ & $f_{5}$ & $F$ \\
\hline 2012 & -0.16976 & 1.113648 & 1.597561 & 0.230809 & - & 0.444558 \\
\cline { 2 - 7 } & - & $*$ & $* * * * *$ & $* * * *$ & - & - \\
\hline 2013 & 1.176561 & -0.09983 & 0.694526 & 1.602919 & 0.2153 & 0.603126 \\
\cline { 2 - 7 } & $*$ & $* *$ & $* * *$ & $* * * * *$ & $* * * *$ & - \\
\hline 2014 & -0.06116 & 1.129931 & 1.342379 & -0.0545 & 0.290064 & 0.455494 \\
\cline { 2 - 7 } & $* *$ & $*$ & Operating & $* * *$ & $* * * *$ & - \\
\hline \multirow{2}{*}{2015} & -0.25182 & 1.373273 & 0.1328719 & 1.486703 & - & 0.477811 \\
\cline { 2 - 7 } & $* *$ & $*$ & $* * *$ & $* * * * *$ & - & - \\
\hline
\end{tabular}


Explain for table 2, table 3 and table 4: *stands for solvency; **stands for profitability; ***stands for development; $* * * *$ stands for cash flow capacity;*****stands for operating capacity.

The results from table 2 show that some common factors do not represent a single ability, so it can not be directly compared with the corresponding ability of each period. From the annual results of Listed Companies in 2013 the issuance of that year, the solvency and operation ability is improved, cash flow capacity is reduced from 1.597561 to 1.602919 , operating capacity, solvency only increased by 0.005358 , from 1.113648 to 1.176561 , increased by 0.062913 , the ability of cash flow from 0.230809 to 0.2153 . The private placement after the first year, to keep the continuous growth of solvency, compared to before the issuance of a year increased by 0.016283 , compared to cash flow ability to significantly enhance the issuance of that year, and higher than before the issuance of 0.059255 a year, compared with the issuance of that year operating capacity is greatly reduced, and less than a year before the issuance of 0.255182 . The private placement of second years, solvency is still maintained continuous growth, than the issuance of the prior year growth of 0.259625 , operating capacity showed fluctuations, although growth has more than in 2014 , but still lower than a year before the issuance of 0.110858 .

Judging from the changes in the overall score of listed companies, the issuance of the comprehensive score was significantly increased from 0.444558 to 0.603126 , an increase of 0.158568 , significantly improved. After the issuance of the first year of comprehensive score compared to the previous year dropped significantly, but still higher than the previous year's comprehensive score. After the issuance of the second year comprehensive score compared with the first year after the issuance, an upward trend, compared with the previous year's comprehensive score increased by 0.033253 .

The empirical results show that the private placement has an impact on the performance of Listed Companies in the year of issuance and the subsequent issuance. Next, we will further analyze the differences between the private placement.

\section{The Impact of Private Placement on the Performance of Listed Companies}

In order to validate the effect of different placement on the operating performance of listed companies, according to the different object placement samples will be divided into two groups, namely 66 Sample Firms offering to new investors oriented and the issuance to the controlling shareholder or related party directed 35 Sample Firms. Using the above model (I) and the model (II) to calculate the common factor score and comprehensive score of each year[10]. The results are shown in Table 3 and table 4.

Table 3 Factor scores and composite scores (new investors)

\begin{tabular}{|c|c|c|c|c|c|c|}
\hline $\begin{array}{l}\text { year } \\
\text { variable }\end{array}$ & $f_{1}$ & $f_{2}$ & $f_{3}$ & $f_{4}$ & $f_{5}$ & $F$ \\
\hline \multirow[t]{2}{*}{2012} & 0.035797 & 0.674151 & 1.140352 & 0.249828 & - & 0.350354 \\
\hline & - & $*$ & $* * * * *$ & $* * * *$ & - & \\
\hline \multirow[t]{2}{*}{2013} & 1.041133 & 0.164253 & 0.912822 & 1.406921 & 0.005446 & 0.608073 \\
\hline & $*$ & $* *$ & $* * *$ & $* * * * *$ & $* * * *$ & \\
\hline \multirow[t]{2}{*}{2014} & 0.015483 & 1.072134 & 0.874585 & 0.132319 & - & 0.417087 \\
\hline & - & $*$ & $* * * * *$ & $* * * *$ & - & \\
\hline \multirow[t]{2}{*}{2015} & -0.15837 & 1.059194 & 0.308567 & 1.058755 & - & 0.415314 \\
\hline & - & $*$ & $* * *$ & $* * * * *$ & - & \\
\hline
\end{tabular}


Table 4 Factor scores and comprehensive scores (controlling shareholders or related parties)

\begin{tabular}{|l|l|l|l|l|l|l|}
\hline \multirow{2}{*}{$\begin{array}{l}\text { year } \\
\text { variable }\end{array}$} & & \multicolumn{1}{|c|}{$f_{1}$} & \multicolumn{1}{c|}{$f_{3}$} & \multicolumn{1}{c|}{$f_{4}$} & $f_{5}$ & $F$ \\
\hline 2012 & & & & & & \\
& 0.392177 & 0.656992 & 0.544234 & -0.63025 & - & 0.272527 \\
\cline { 2 - 7 } & - & $*$ & $* * * *$ & - & - & - \\
\hline \multirow{2}{*}{2013} & 1.016405 & -0.29959 & 0.711112 & 1.606458 & - & 0.563099 \\
\cline { 2 - 7 } & - & $* *$ & $* * *$ & $* * * *$ & - & - \\
\hline \multirow{2}{*}{2014} & -0.05617 & 1.131986 & 1.344294 & -0.03271 & - & 0.443416 \\
\cline { 2 - 7 } & $* *$ & $*$ & $* * * *$ & - & - & - \\
\hline \multirow{2}{*}{2015} & -0.4497 & 0.357866 & 1.637772 & 1.669946 & - & 0.612979 \\
\cline { 2 - 7 } & $* *$ & - & $*$ & $* * * * *$ & - & - \\
\hline
\end{tabular}

Capacity Comparison Analysis. Solvency. From table 3 and table 4 results can be seen, the issuance of new investors private listed companies, its solvency is superior to the prior to the issue of controlling shareholders or related parties of the listed company shares, but the difference is not big, only 0.017158 . The first year after the issuance of the directional and second years, to new investors private placement of listed company's solvency worse than the issuance of related parties or controlling shareholders of listed companies, and the gap is more and more big, the first year is 0.059852 , second years is 0.578578 . From the empirical results of two samples of each trend, to new investors after placement of listed company's solvency is getting worse, and to the controlling shareholder or related parties of the listed company shares solvency better. Thus, the listed company to the controlling shareholder or related party issuance can better enhance the solvency of listed companies.

Operating capacity. From table 3 and table 4 results can be seen, the listed company to new investors private placement year working ability in the issuance to the controlling shareholder or related party of listed companies, and in the two year after the issuance of the two listed companies operating capacity showed a V type change. But to new investors private placement of listed companies operating capacity lower than the issuance of controlling shareholders or related parties of listed companies, and the gap is more and more big, the first year is 0.469709 , the second year gap is 0.611191 . The results show that the placement of the two listed companies operating ability similar to the mechanism of influence, but to the controlling shareholder or related private placement of a negative effect on the operating capacity of less than the issuance of new investors private listed companies.

Other capabilities. From the results of table 3 and table 4, we can see that the cash flow capacity, profitability and development ability of listed companies with different objects are not comparable.

Comprehensive Analysis of Business Performance. It can be seen from table 3, the listed companies to the new investment in that year, the company's comprehensive performance scores than the rise from 0.350354 to 0.608073 ; the first year after the issuance of the issuance of that year than decreased, decreased by 0.190986; second years after the issuance of comprehensive performance scores remained down, 0.001773 lower than the issuance of the first year of comprehensive score. But the decline is weak. Overall, the performance of listed companies to new investors in the performance of the comprehensive score was excellent, but the overall performance score of the year after year decreased, but higher than the previous year's performance score.

As can be seen from table 4, to the controlling shareholders or related parties of private placement of listed companies, the annual changes in the overall score and the new investors to the listed companies to show a different law. The issuance of that year, the listed company comprehensive score increased from 0.272527 to 0.563099 ; the private placement after the first year, the comprehensive performance score of 0.563099 to 0.443416 by the issuance of that year; second years after the issuance of the comprehensive performance score compared to the first year 
after the issuance will rise, an increase of 0.169563 . Overall, the issuance to the controlling shareholder or related party orientation of listed companies, its comprehensive performance scores in the issuance of that year outstanding performance, although after the issuance of the first year has decreased, but after the issuance of second years rose contrarian and score two year after the issuance of the comprehensive performance was higher than that before the issuance of a year, and the comprehensive performance of the issuance of second years it is good for the issuance of that year.

Through a comprehensive comparative analysis of the operating performance, we found that the issuance of the controlling shareholder or related party oriented listed company, operating performance before private placement is not better than the issuance of new investors private listed companies, and the performance is still poor in the issuance of that year to new investors private placement of listed companies, but the additional to the controlling shareholder the related party of listed companies or the issuance of that year performance rises more than the issuance of new investors private listed companies. In the first year after issuance, the operating performance of the two types of listed companies have shown a decline, but to the controlling shareholder or affiliated party of the listed company's decline is less than the new investors to the private placement of listed companies. Second years after the issuance, two kinds of operating performance of listed companies shows the opposite trend, business or related to the controlling shareholder of Fang Zengfa's performance of listed companies increased significantly, and decreased to new investors private placement of the operating performance of listed companies. The results show that there is a significant positive impact on the listed companies to the controlling shareholders or related parties.

\section{Summary}

In this paper, we use factor analysis to conduct a comprehensive analysis of the performance of 101 listed companies in 2013:

The private placement of listed companies has a significant role in improving the performance of the current year, and has a positive impact on the performance of the next year. The private placement in the operating results of listed companies significantly, shows that the private placement of short-term business performance of listed companies to enhance the good promotion effect; two business performance after private placement was inferior to the issuance of that year, but were better than a year before the issuance of the business performance, and showed a rising trend. Therefore, it can be concluded that the private placement has a positive impact on the long-term performance of listed companies.

The performance of private placement to controlling shareholders or related parties is better than that of new investors. From the issuance to different object oriented performance of listed companies performance, the issuance of two specific objects of the listed company, its performance in the issuance of that year are excellent; two years after issuance, the issuance to the controlling shareholder or related party oriented company, its performance is better than the issuance of new investors private listed the company, and the issuance of the controlling shareholder or related party oriented corporate performance is on the rise, and the issuance of new investors oriented corporate performance decline. Therefore, it can be concluded that the private placement of listed companies to controlling shareholders or related parties has a more significant positive effect on the company's operating performance.

\section{References}

[1] W.D.Zhang and H.C. Li: Accounting Research, 2010,03:58-64+97.(In Chinese)

[2] P.Zhang and J.Yu: Accounting Monthly, 2015,27:35-38.(In Chinese)

[3] Hertzel M and Rees L. Performance Private of Journal of Finance, 2002, 57 (6): 2595-2617.

[4] Barclay M J, Holderness C G and Sheehan D: Ssrn Electronic Journal, 2007, 13 (4): 461-484. 
[5] W.d.Zhang : Management World, 2008,04:179-180.(In Chinese)

[6] L.Deng and H.C.Wang:Accounting Research, 2014,11:38-45+96.(In Chinese)

[7] F.Guan, Q.L.Jin and P.P.Zhang:Financial Research, 2015, 41:132-144.(In Chinese)

[8] L.X.Wu: Foreign Trade and Economics, 2016, 01: 85-90.(In Chinese)

[9] W.D.Zhang, C.Yuan and J.K.Zhang: Finance and Trade Research. 2014,04: 145-151.(In Chinese)

[10]L.X.Zhang and C.X.Liu: International Business Accounting, 2014 ,09: 60-63.(In Chinese) 